\title{
Incidence and clinical relevance of cage subsidence in anterior cervical discectomy and fusion: a systematic review
}

\author{
Iris Noordhoek ${ }^{1}$ (D) - Marvyn T. Koning ${ }^{2} \cdot$ Wilco C. H. Jacobs ${ }^{1} \cdot$ Carmen L. A. Vleggeert-Lankamp $^{1}$
}

Received: 10 January 2018 / Accepted: 7 February 2018 / Published online: 21 February 2018

(C) The Author(s) 2018. This article is an open access publication

\begin{abstract}
Background The placement of intervertebral cages in anterior cervical discectomy (ACDF) supposedly maintains foraminal height. The most commonly reported cage-related complication is subsidence, although it is unknown whether a correlation between subsidence and clinical outcome exists.

Aim To assess the incidence and relevance of subsidence.

Methods Literature searches were performed in PubMed, MEDLINE, Embase, Web of Science, COCHRANE, and CENTRAL. The inclusion criteria were as follows: $\geq 20$ patients, ADCF with cage, subsidence assessed, and primary data. Risk of bias was assessed using adjusted Cochrane checklists.

Results Seventy-one studies, comprising 4784 patients, were included. Subsidence was generally defined as $\geq 3$-mm loss of height comparing postoperative intervertebral heights with heights at last follow-up. Mean incidence of subsidence was $21 \%$ (range $0-83 \%$ ). Of all patients, $46 \%$ of patients received polyether-ether-ketone (PEEK) cages, $31 \%$ received titanium cages, $18 \%$ received cage-screw-combinations, and 5\% received polymethyl-methacrylate (PMMA) cages. Patients treated with cagescrew-combinations had significantly less subsidence than patients treated with PEEK, titanium, or PMMA cages (15.1\% vs. $23.5 \%$ vs. $24.9 \%$ vs. $30.2 \% ; p<0.001)$. Thirteen studies assessed clinical outcome in relation to subsidence; the majority did not find a significant correlation. Only four studies correlated subsidence to cage size and/or height; no correlation was established. Conclusions Subsidence in ACDF with cages occurs in $21 \%$ of patients. The risk for subsidence seems lower using PEEK or titanium cages or adding screws. Whether subsidence affects clinical outcome is not satisfactorily evaluated in the available literature. Future studies on this correlation are warranted in order to establish the additional value of the interposition of a cage in ACDF.
\end{abstract}

Keywords Anterior discectomy $\cdot$ Fusion $\cdot$ Cage $\cdot$ Subsidence

\section{Introduction}

Anterior cervical discectomy and fusion (ACDF) is a commonly used procedure to decompress cervical spinal nerves or the cervical medulla in case of predominant anterior compression. The discectomy provides decompression of the nervous tissue, while placing an intervertebral device, secured with or without anterior plating, maintains foraminal height, and ideally promotes eventual fusion. The intervention affords

Iris Noordhoek

i.noordhoek@lumc.nl

1 Department of Neurosurgery, Leiden University Medical Center, Albinusdreef 2, 2300 RC Leiden, the Netherlands

2 Department of Hematology, Leiden University Medical Center, Leiden, the Netherlands segmental stability and solid arthrodesis and carries minimal surgical risks [10, 14, 41].

When ACDF first became a well-accepted procedure in the 1950 s, it was performed using autologous bone grafts obtained from the anterior iliac crest. However, this technique had several limitations, such as graft collapse or expulsion, pseudarthrosis, and significant donor-site morbidity. A remarkable number of cases showed subsidence, giving rise to loss of intervertebral height in the follow-up period $[4,7,40]$. Since then, cages have been introduced to replace the bone grafts, involving synthetic materials such as stainless steel, titanium, carbon fiber, polymethyl-methacrylate (PMMA), and polyether-ether-ketone (PEEK). In theory, the artificial cage types have the ability of restoration and preservation of disc height and lordosis, as well as the ability to prevent graft collapse or resorption [16, 27].

Although cages can differ in shape and material, they are all intended to maintain height and to add to immobilization of 
the degenerated motion segment. Ideally, cages serve as a scaffold to promote interbody fusion. However, side effects such as non-union, cage subsidence, and consequent kyphotic malalignment of the cervical spine are known to occur [38].

Since one of the goals of placing an intervertebral cage after anterior discectomy is to maintain foraminal height, it would be insinuated that cage subsidence is a particularly incapacitating complication, as this directly violates that goal. However, some surgeons perform this procedure without using an intervertebral device, and satisfactory results have been described as well [18, 30]. It is of interest to investigate whether the theoretical advantage of maintaining height is of clinical importance. Besides loss of height, cage subsidence can secondarily lead to pseudarthrosis, which causes (micro-)instability. Instability can lead to induction of bone formation by osteophytes, which can subsequently lead to recurring nerve root compression. Likewise, it is noteworthy to be informed on the correlation between subsidence and clinical result.

The primary objective of this systematic review is to determine the occurrence of cage subsidence after a cervical anterior discectomy with use of an intervertebral cage. Secondary objectives are to assess which dimensional aspects of the cage are related to subsidence, what qualifications the cages should meet in order to minimize the extent of this event, and whether there is a correlation between clinical outcome and cage subsidence.

\section{Materials and methods}

\section{Data searches and study selection}

In order to obtain all relevant literature, the electronic databases PubMed, MEDLINE, Embase, Web of Science, COCHRANE, and CENTRAL were searched in January 2015. The search strings presented in Fig. 1 were used. According to PRISMA guidelines, two of the authors (IN and MTK) individually and independently screened the articles for predefined inclusion criteria. These were stated as followed:

- The article was published in English or Dutch;

- The article was an original report presenting primary data;

- The article was published on or after 1 January 2000;

- The study had a minimum of 20 patients;

- The study reported a loss to follow-up of less than $20 \%$;

- The study focused on the cervical spine (C2-Th1);

- The study presented patients undergoing anterior cervical discectomy and fusion with a cage;

- The study made an assessment of cage subsidence;

- The article was published in a peer-reviewed journal.

Only studies that the evaluators reached a consensus on were included. If needed, a third reviewer (CVL) was consulted.

\section{Quality assessment}

To assess the quality of the selected studies, the studies were evaluated with the aid of an adjusted version of the checklist for cohort studies of the Dutch Cochrane Centre, presented in Table 1. The methodological requirements and objectives of these studies were closely evaluated. This was done individually and independently by two reviewers (IN and CVL). A third reviewer (WJ) was consulted in case of inconsistency. Studies were assessed on selection bias, for which a maximum of three points could be attributed; outcome bias, with a maximum of three points; follow-up bias, with a maximum of two points; and other bias, with a maximum of three points. In total, a study could be awarded a maximum of 11 points. Studies were then divided into a low ( $8-11$ points), intermediate (6-7 points), or high (5 or less points) risk of bias group.

\section{Data extraction}

All data from the included studies were analyzed and data regarding the following items were extracted:

- Number of participating patients;

- Mean incidence of subsidence;

- Distribution of patients over different cage types and correlation of cage type to subsidence;

- Clinical outcome and correlation to subsidence;

- Contact area and height of the cage and correlation to subsidence.

\section{Statistical analysis}

Statistical analyses were done using Statistical Package for the Social Sciences (SPSS) version 22 (IBM, Armonk, NY, USA). Descriptive analysis was used to evaluate the data of this systematic literature review. To calculate the influence of the type of intervertebral cage on the incidence of subsidence, Fisher's exact tests were used.

\section{Results}

\section{Characteristics of included studies}

Through our search, 1866 studies were identified. After matching these to our inclusion criteria, 71 studies were included. The most common grounds to exclude studies were as follows: studies appeared to be animal or cadaver studies, subsidence was not properly described, patient numbers were too small, and loss to follow-up was more than $20 \%$. The 71 included studies stated a clear definition 
Fig. 1 Search strings used for the data search in January 2015

\section{Total at 13-01-2015: 1.866 unique articles, originating from:}

\section{PubMed: 1.551 results}

("Diskectomy"[Mesh] OR "discectomy"[all fields] OR "diskectomy"[all fields] OR discectom*[all fields] OR diskectom*[all fields] OR "ACDF"[tiab]) AND ("Cervical Vertebrae"[Mesh] OR "cervical spine"[all fields] OR "Cervical Vertebrae"[all fields] OR "Axis"[all fields] OR "Odontoid Process"[all fields] OR "Cervical Atlas"[all fields] OR "Cervical"[all fields]) AND ("Prosthesis Implantation"[Mesh] OR "Prostheses and Implants"[Mesh] OR "prosthesis"[all fields] OR "prosthetic"[all fields] OR "prostheses"[all fields] OR "prosthetics"[all fields] OR prosthe*[all fields] OR "cage"[all fields] OR "Spinal Fusion"[Mesh] OR "Spinal Fusion"[all fields] OR "implant"[all fields] OR "implants"[all fields] OR "implantation"[all fields] OR "interbody"[all fields] OR "spacer"[all fields])

\section{MEDLINE: 1.241, 0 unique}

Same strategy as used in PubMed, adjusted for this database.

Embase: 959 results, 247 unique

Same strategy as used in PubMed, adjusted for this database.

Web of Science: 270 results, 31 unique

Same strategy as used in PubMed, adjusted for this database.

\section{COCHRANE: 212 results, 36 unique}

Same strategy as used in PubMed, adjusted for this database.

CENTRAL: 175 results, 1 unique

Same strategy as used in PubMed, adjusted for this database. of subsidence and scored the incidence. Combining all these studies resulted in a cohort of 4784 patients, of whom 2216 received a PEEK cage, 1494 received a titanium cage, 833 received a combination of a cage and screws (cage-screw-combination, CSC), and 241 received a PMMA cage.

\section{Risk of bias}

Twenty-eight studies were assessed to have a low risk of bias, 29 studies had an intermediate risk of bias, and 14 studies showed a high risk, mainly due to selection and follow-up bias (Table 2).

\section{Incidence of cage subsidence}

Subsidence was generally defined as $\geq 3 \mathrm{~mm}$ loss of height comparing the direct postoperative intervertebral height with the intervertebral height at the last follow-up moment. The mean incidence of subsidence was $21.1 \%$, ranging from studies reporting $0 \%[1,2,12,13,15,22,26,28,29,34,37,39]$ to
1 study reporting $83 \%$ [5]. When excluding the 14 studies with a high risk of bias from calculations, mean incidence of subsidence is $20.2 \%$ (range $0-83 \%$ ).

\section{Correlation subsidence and clinical outcome}

Clinical outcome was assessed in relation to subsidence in 13 studies $[5,8,9,11,17,20,23-25,33,35,45,48]$. Of these, 7 had a low risk of bias, 5 had an intermediate risk of bias, and 1 study had a high risk of bias. Of these 13 studies, 3 found a statistically significant correlation between a worse clinical outcome and the occurrence of subsidence [20, 23, 25]. The study by Kast et al. prospectively evaluated clinical outcome using the Odom scale [20]. The study by Kim et al. evaluated clinical outcome using the Odom scale as well, though in a retrospective manner from notes in the patients' charts [23]. The study by Lee et al. evaluated clinical outcome through a visual analogue scale (VAS) for neck and arm pain. In the subsidence group, the VAS score for neck pain was 3.9 versus 2.5 in the non-subsidence group. The VAS score for arm pain was 3.7 in the subsidence group and 1.8 in the non-subsidence 
Table 1 Quality assessment checklist

\begin{tabular}{|c|c|}
\hline Section & Award 1 point if \\
\hline \multicolumn{2}{|l|}{ Selection bias (3 pts.) } \\
\hline Goal and inclusion & $\begin{array}{l}\text { Goal of the study is stated and study } \\
\text { explicitly states the inclusion criteria }\end{array}$ \\
\hline Selection of patients & $\begin{array}{l}\text { Selective recruitment of patients can be } \\
\text { ruled out }\end{array}$ \\
\hline Patient characteristics & $\begin{array}{l}\text { Study reports the age range and mean age } \\
\text { and states the distribution of men and } \\
\text { women }\end{array}$ \\
\hline \multicolumn{2}{|l|}{ Outcome bias (3 pts.) } \\
\hline Definition of subsidence & $\begin{array}{l}\text { Definition of subsidence, classification, and } \\
\text { radiological tools to measure subsidence } \\
\text { were stated }\end{array}$ \\
\hline Clinical outcome & $\begin{array}{l}\text { Clinical outcome was systematically } \\
\text { evaluated in correlation to subsidence }\end{array}$ \\
\hline Preoperative status & $\begin{array}{l}\text { Preoperative status was stated for } \\
\text { comparison with postoperative status }\end{array}$ \\
\hline \multicolumn{2}{|l|}{ Follow-up bias (2 pts.) } \\
\hline Follow-up period & $\begin{array}{l}\text { Follow-up range, period, and mean were } \\
\text { given: } \\
\text { - If yes and prospective study: } 2 \text { points } \\
\text { - If yes and retrospective study: } 1 \text { point } \\
\text { - If no, but loss to follow-up < } 20 \%: 1 \text { point } \\
\text { - If too little information: } 0 \text { points }\end{array}$ \\
\hline \multicolumn{2}{|l|}{ Other bias (3 pts.) } \\
\hline Clinical evaluation & $\begin{array}{l}\text { Evaluation was done independently from } \\
\text { treating physician }\end{array}$ \\
\hline Radiologic evaluation & $\begin{array}{l}\text { Evaluation was done by an independent } \\
\text { party, blinded to clinical results }\end{array}$ \\
\hline Independence & $\begin{array}{l}\text { Independence is explicitly stated, conflict of } \\
\text { interest can be ruled out }\end{array}$ \\
\hline Total (11 points) & \\
\hline
\end{tabular}

group [25]. The other 10 studies did not find a correlation between clinical outcome and the occurrence of subsidence. These studies generally used a larger variety of measures to evaluate clinical outcome and collected data prospectively in 4 studies $[5,9,17,33]$, and retrospectively in 6 studies $[8,11$, 24, 35, 45, 48] (Table 3).

Table 2 Average amount of points in each risk of bias section when studies are assigned to a low, intermediate, or high risk of bias group

\begin{tabular}{llllll}
\hline & $\begin{array}{l}\text { Selection } \\
\text { bias } \\
(3 \text { pts. })\end{array}$ & $\begin{array}{l}\text { Outcome } \\
\text { bias } \\
(3 \text { pts. })\end{array}$ & $\begin{array}{l}\text { Follow-up } \\
\text { bias } \\
(2 \text { pts. })\end{array}$ & $\begin{array}{l}\text { Other } \\
\text { bias } \\
(3 \text { pts. })\end{array}$ & $\begin{array}{l}\text { Total } \\
(11 \text { pts. })\end{array}$ \\
\hline Low (28) & 2.0 & 2.9 & 1.6 & 2.1 & 8.7 \\
Intermediate (29) & 1.6 & 2.3 & 1.2 & 1.6 & 6.6 \\
High (14) & 1.1 & 1.9 & 0.8 & 0.8 & 4.6 \\
Total (71) & 1.7 & 2.4 & 1.3 & 1.6 & 7.0 \\
\hline
\end{tabular}

\section{Correlation subsidence and material of cage}

The different types of cages that were used are PEEK, titanium, CSC, and PMMA. Of all patients, $46 \%$ were treated with PEEK cages, $31 \%$ with titanium cages, $18 \%$ with CSC, and $5 \%$ with PMMA cages. The mean incidence of subsidence in patients receiving a PEEK cage was $23.5 \%$. Of all patients that received a titanium cage, $24.9 \%$ suffered from subsidence. In patients with a CSC, it was $15.1 \%$; and in patients receiving PMMA cages, subsidence occurred in $30.2 \%$ (Table 4).

In patients treated with PMMA cages, there was a significantly higher incidence of subsidence than in patients treated with PEEK cages $(p=0.049)$ and CSC $(p<0.001)$. In patients treated with CSC, there was a significantly lower incidence of subsidence than in patients treated with PEEK, PMMA, or titanium cages $(p<0.001)$. There was no statistically significant difference between the incidence of subsidence between PEEK and titanium cages, nor between PMMA and titanium cages.

\section{Correlation subsidence and dimensional aspects of cage}

Dimensional aspects of the cages were described in 16 studies $[3,6,17,19-21,31,32,34,36,37,42-44,46,47]$. Only 4 of these assessed the dimensional aspects in relation to subsidence $[6,44,46,47]$, of which 1 study showed an increased risk of subsidence with a larger height of the cage (quote: "A cage size of 6.5 or $7.5 \mathrm{~mm}$ had a significantly higher risk of cage subsidence compared with 4.5 or $5.5 \mathrm{~mm}(\mathrm{p}=0.037) . ”)$ [46]. Another study showed a decreased risk of subsidence with a larger size of the contact surface of the cage (quote: "the use of $14 \mathrm{~mm}$-diameter cages led to a significantly less risk for subsidence than using $12 \mathrm{~mm}$-diameter cages $(\mathrm{p}=$ 0.034; odds ratio, 0.017)") [47]. The other 2 studies did not find a correlation between the size or height of the cage and the occurrence of subsidence $[6,44]$. These 4 studies all had a low risk of bias.

\section{Discussion}

From the data presented in literature, it can be concluded that cage subsidence is a substantial side effect of intervertebral cage implantation in ACDF, with an overall incidence of $21 \%$. However, the majority of studies correlating clinical outcome to the occurrence of subsidence did not find a negative clinical outcome with subsidence. The studies that did find a statistically significant correlation between worse clinical outcome and subsidence used the Odom scale for clinical outcome or a VAS score for pain. The Odom scale is a very rough scale (four options: very good, good, bad, and very bad) and in neither of the two studies was it indicated how the scale 
Table 3 Clinical outcome was assessed in correlation to subsidence in 13 studies

\begin{tabular}{|c|c|c|c|c|c|}
\hline Reference & $\begin{array}{l}\text { Bias } \\
\text { score }\end{array}$ & $\begin{array}{l}N \text { with subsidence/ } \\
\text { total }(\%)\end{array}$ & Type of outcome measure & Study design & Correlation \\
\hline Kast et al. [20] & 10 & $15 / 52(29)$ & Odom's criteria & Prospective & $\begin{array}{l}\text { Subsidence was correlated to worse } \\
\text { outcome, } p=0.039\end{array}$ \\
\hline Kim et al. [23] & 7 & $13 / 48(27)$ & Odom's criteria & Retrospective & $\begin{array}{l}\text { Subsidence was correlated to worse } \\
\text { outcome after } 6 \text { weeks }(p=0.021) \\
3 \text { months }(0.002), 6 \text { months } \\
(p=0.001), \text { and } 12 \text { months } \\
(p=0.05)\end{array}$ \\
\hline Lee et al. [25] & 7 & $26 / 78(33)$ & VAS for neck and arm pain & Retrospective & $\begin{array}{l}\text { At last FU, the VAS score in the } \\
\text { subsidence group was higher than in } \\
\text { the non-subsidence group, } p<0.001\end{array}$ \\
\hline Chiang et al. [8] & 6 & $8 / 56(14)$ & Odom's criteria & Retrospective & $\begin{array}{l}\text { The satisfaction rate of subsidence } \\
\text { cases seemed to be lower than that of } \\
\text { the total population. However, this } \\
\text { was not statistically significant }\end{array}$ \\
\hline Brencke et al. [5] & 8 & $66 / 80(83)$ & $\begin{array}{l}\text { VAS for neck pain, NDI, } \\
\text { and PSI }\end{array}$ & Prospective & No correlation \\
\hline Cho et al. [9] & 8 & $1 / 60(2)$ & $\begin{array}{l}\text { Prolo scale for myelopathy } \\
\text { and radiculopathy }\end{array}$ & Prospective & No correlation \\
\hline Dogan et al. [11] & 7 & $10 / 22(47)$ & $\begin{array}{l}\text { Nurick scale for } \\
\text { myelopathy and Odom's } \\
\text { criteria }\end{array}$ & Retrospective & No correlation \\
\hline Hwang et al. [17] & 5 & $3 / 78(4)$ & $\begin{array}{l}\text { VAS for neck pain, Odom's } \\
\text { criteria }\end{array}$ & Prospective & No correlation \\
\hline Klingler et al. [24] & 7 & $39 / 107(36)$ & $\begin{array}{l}\text { VAS (not specified), NDI, } \\
\text { SF-36, and PSI }\end{array}$ & Retrospective & No correlation \\
\hline Orief et al. [33] & 9 & $1 / 38(3)$ & $\begin{array}{l}\text { VAS for neck and arm pain } \\
\text { and Odom's criteria }\end{array}$ & Prospective & No correlation \\
\hline Park et al. [35] & 8 & $7 / 31(23)$ & $\begin{array}{l}\text { VAS (not specified), NDI, } \\
\text { and Odom's criteria }\end{array}$ & Retrospective & No correlation \\
\hline Wu et al. [45] & 10 & $10 / 57(18)$ & $\begin{array}{l}\text { JOA score for myelopathy, } \\
\text { VAS for neck and arm } \\
\text { pain }\end{array}$ & Retrospective & No correlation \\
\hline Yoo et al. [48] & 10 & $18 / 58(31)$ & $\begin{array}{l}\text { VAS for neck and arm pain, } \\
\text { NDI, and Odom's } \\
\text { criteria }\end{array}$ & Retrospective & No correlation \\
\hline
\end{tabular}

$J O A$ the Japanese Orthopedic Association, VAS visual analogue scale, NDI neck disability index, PSI patient satisfaction index, SF-36 Short Form 36 Health Survey, $F U$ follow-up

was dichotomized in order to draw conclusions. Furthermore, results were evaluated retrospectively in 2 of the 3 studies. Moreover, in all studies, the number of patients was limited (Table 3). In these three studies, on average, 50-70 patients were included, indicating that 10-14 patients per study suffered from subsidence (21\%). Most studies that did not find a correlation between subsidence and clinical outcome collected their data retrospectively and used various types of outcome measures. The validity of the results in these studies is therefore debatable. In conclusion, it is neither possible to conclude that subsidence impacts the clinical outcome in a negative way, nor to conclude that subsidence does not impact clinical outcome at all.

Cages are introduced to maintain foraminal height to prevent the nerve root from being compressed in the neuroforamina after decompression. The foraminal height is frequently compromised after surgery, since the bulging disc is often accompanied by bony degeneration, leading to osteofytary rims with partial destruction of the uncinate process. Therefore, decompression of the cervical spinal nerve

Table 4 Overview distribution of subsidence and patients over different cage types

\begin{tabular}{llllll}
\hline & PEEK & Titanium & CSC & PMMA & Total \\
\hline Studies $(n)$ & 44 & 27 & 16 & 6 & 71 \\
Patients $(n)$ & 2216 & 1494 & 833 & 241 & 4784 \\
Subsidence (\%) & 23.5 & 24.9 & 15.1 & 30.2 & 21.1 \\
Average ROB & 7.2 & 7.0 & 6.4 & 7.3 & 7.0 \\
\hline
\end{tabular}

$R O B$ risk of bias, $P E E K$ polyether-ether-ketone, $C S C$ cage-screw-combination, $P M M A$ polymethyl-methacrylate 
root usually comprises not only removal of disc tissue, but also removal of the bony rims, which damages the uncinate process. However, if the surgeon only removes the bulging disc tissue without damaging the uncinate process, the foraminal height can be maintained independently of the presence of an intervertebrate device.

Since none of the articles described the precise surgical procedure, no information on the integrity of the uncinate process is available. However, regardless of the integrity of the uncinate process, if loss of height of more than $3 \mathrm{~mm}$ (definition of subsidence) is not causing clinical symptoms, the urge to maintain foraminal height is debatable. Nevertheless, prevention of kyphosis and pseudarthrosis can still be regarded as beneficial effects of a cage, but these aspects have not been studied in the articles describing subsidence in ACDF.

A statistically significant correlation was found between the type of cage that was used and the occurrence of subsidence. CSCs seemed to have the least occurrence of subsidence, which only seems logical since the screws force the cage to be placed in the anterior cortical plane and additionally the screws themselves are placed cortically. The studies evaluating CSC generally had an intermediate risk of bias and were judged to be of adequate quality to base conclusions on. PMMA cages were found to have the highest occurrence of subsidence $(30.2 \%)$, which is not only statistically higher than the general occurrence of subsidence $(21.1 \%)$, but presumably also clinically relevant. The studies evaluating PMMA cages generally had a low risk of bias and are therefore valid studies to support the conclusion that PMMA cages should be avoided in ACDF when aiming to avoid subsidence. The differences between PEEK and titanium cages were not large enough to reach statistical significance, which leads to the conclusion that using either of those results in comparable outcome.

The prospective study by Yamagata et al. found that "a cage height of 6.5 or $7.5 \mathrm{~mm}$ had a significantly higher risk of cage subsidence compared with a height of 4.5 or $5.5 \mathrm{~mm}$ $(p=0.037)$ " [46]. This translates to larger heights of cages lead to more subsidence. This can be explained by the larger amount of stress on the vertebral endplates, which presumably results in subsidence. The retrospective study by Yang et al. found that "the use of $14 \mathrm{~mm}$-diameter cages led to a significantly less risk for subsidence than using $12 \mathrm{~mm}$-diameter cages ( $p=0.034$; odds ratio, 0.017$)$ " [47]. This shows a decreased risk of subsidence with a larger size of the contact surface of the cage. However, it was not studied whether a diameter of for instance 18 or $22 \mathrm{~mm}$ leads to even fewer occurrences of subsidence, or whether perhaps there is an optimal diameter. The retrospective studies by van Jonbergen et al. [44] and Cabraja [6] only briefly mention that subsidence was not related to cage size. These studies did not discuss in detail what cage size or height they studied or how they performed their analyses. These 4 studies on cage size all had a low risk of bias. In summary, cage size and height cannot be excluded as risk factors for subsidence and these studies show interesting results; however, there is too little data to draw solid conclusions.

\section{Conclusion}

Subsidence in ACDF using a cage occurs in $21 \%$ of patients. Based on the current review, the risk for subsidence seems to be lower when a PEEK or titanium cage is used, or when a cage with integrated screws is used. The correlation of subsidence with kyphosis or pseudarthrosis is not sufficiently addressed in the available literature. It is not satisfactorily evaluated whether subsidence affects clinical outcome. Future studies on these correlations are warranted in order to properly establish the value of the interposition of a cage in ACDF.

Funding No funding was received for this research.

\section{Compliance with ethical standards}

Conflict of interest The authors declare that they have no conflict of interest.

Ethical approval This article does not contain any studies with human participants performed by any of the authors.

Open Access This article is distributed under the terms of the Creative Commons Attribution 4.0 International License (http:// creativecommons.org/licenses/by/4.0/), which permits unrestricted use, distribution, and reproduction in any medium, provided you give appropriate credit to the original author(s) and the source, provide a link to the Creative Commons license, and indicate if changes were made.

\section{References}

1. Akula M, Taha M, Mathew B, O'Reilly G (2008) The plate cage Benezech implant as an alternative to autologous bone graft in the treatment of cervical spondylosis: clinical and functional outcome. Br J Neurosurg 22:542-545. https://doi.org/10.1080/ 02688690802057326

2. Ba Z, Zhao W, Wu D, Shen B, Yu B, Wang Z (2012) Box cages packed with local decompression bone were efficient in anterior cervical discectomy and fusion: five- to 10 -year follow-up. Spine 37:E1260-E1263. https://doi.org/10.1097/BRS. 0b013e318265df75

3. Bartels RH, Donk RD, Feuth T (2006) Subsidence of stand-alone cervical carbon fiber cages. Neurosurgery 58:502-508; discussion 502-508. https://doi.org/10.1227/01.neu.0000197258.30821.50

4. Bishop RC, Moore KA, Hadley MN (1996) Anterior cervical interbody fusion using autogeneic and allogeneic bone graft substrate: a prospective comparative analysis. J Neurosurg 85:206210. https://doi.org/10.3171/jns.1996.85.2.0206 
5. Brenke C, Dostal M, Scharf J, Weiss C, Schmieder K, Barth M (2015) Influence of cervical bone mineral density on cage subsidence in patients following stand-alone anterior cervical discectomy and fusion. European spine journal : official publication of the European Spine Society, the European Spinal Deformity Society, and the European Section of the Cervical Spine Research Society 24:2832-2840. https://doi.org/10.1007/s00586-014-3725-9

6. Cabraja M, Oezdemir S, Koeppen D, Kroppenstedt S (2012) Anterior cervical discectomy and fusion: comparison of titanium and polyetheretherketone cages. BMC Musculoskelet Disord 13: 172. https://doi.org/10.1186/1471-2474-13-172

7. Cauthen JC, Kinard RE, Vogler JB, Jackson DE, DePaz OB, Hunter OL, Wasserburger LB, Williams VM (1998) Outcome analysis of noninstrumented anterior cervical discectomy and interbody fusion in 348 patients. Spine 23:188-192

8. Chiang CJ, Kuo YJ, Chiang YF, Rau G, Tsuang YH (2008) Anterior cervical fusion using a polyetheretherketone cage containing a bovine xenograftp: three to five-year follow-up. Spine 33: 2524-2428. https://doi.org/10.1097/BRS.0b013e318185289c

9. Cho DY, Lee WY, Sheu PC (2004) Treatment of multilevel cervical fusion with cages. Surg Neurol 62:378-385, discussion 385-376. https://doi.org/10.1016/j.surneu.2004.01.021

10. Cloward RB (1958) The anterior approach for removal of ruptured cervical disks. J Neurosurg 15:602-617. https://doi.org/10.3171/ jns.1958.15.6.0602

11. Dogan S, Turkkan A, Kocaeli H, Korfali E, Bekar A (2008) Clinical and radiologic analysis of 3-level anterior cervical discectomy and fusion with interbody cages without plate fixation. Neurosurg Q 18: 188-194

12. Dufour T, Huppert J, Louis C, Beaurain J, Stecken J, Aubourg L, Vila T (2010) Radiological analysis of 37 segments in cervical spine implanted with a peek stand-alone device, with at least one year follow-up. Br J Neurosurg 24:633-640. https://doi.org/10.3109/ 02688691003793029

13. Elsawaf A, Mastronardi L, Roperto R, Bozzao A, Caroli M, Ferrante L (2009) Effect of cervical dynamics on adjacent segment degeneration after anterior cervical fusion with cages. Neurosurg Rev 32:215-224; discussion 224. https://doi.org/10.1007/s10143008-0164-2

14. Fowler SB, Anthony-Phillips P, Mehta D, Liebman K (2005) Healthrelated quality of life in patients undergoing anterior cervical discectomy fusion. The Journal of neuroscience nursing : journal of the American Association of Neuroscience Nurses 37:97-100

15. Grasso G, Giambartino F, Tomasello G, Iacopino G (2014) Anterior cervical discectomy and fusion with ROI-C peek cage: cervical alignment and patient outcomes. European spine journal : official publication of the European Spine Society, the European Spinal Deformity Society, and the European Section of the Cervical Spine Research Society 23 Suppl 6:650-657. https://doi.org/10. 1007/s00586-014-3553-y

16. Hacker RJ, Cauthen JC, Gilbert TJ, Griffith SL (2000) A prospective randomized multicenter clinical evaluation of an anterior cervical fusion cage. Spine 25:2646-2654 discussion 2655

17. Hwang SL, Hwang YF, Lieu AS, Lin CL, Kuo TH, Su YF, Howng SL, Lee KS (2005) Outcome analyses of interbody titanium cage fusion used in the anterior discectomy for cervical degenerative disc disease. J Spinal Disord Tech 18:326-331

18. Jacobs W, Willems PC, Kruyt M, van Limbeek J, Anderson PG, Pavlov P, Bartels R, Oner C (2011) Systematic review of anterior interbody fusion techniques for single- and double-level cervical degenerative disc disease. Spine 36:E950-960. https://doi.org/10. 1097/BRS.0b013e31821cbba5

19. Kao FC, Niu CC, Chen LH, Lai PL, Chen WJ (2005) Maintenance of interbody space in one- and two level anterior cervical interbody fusion: comparison of the effectiveness of autograft, allograft, and cage. Clin Orthop Relat Res 108-116
20. Kast E, Derakhshani S, Bothmann M, Oberle J (2009) Subsidence after anterior cervical inter-body fusion. A randomized prospective clinical trial. Neurosurgical review 32:207-214; discussion 214. https://doi.org/10.1007/s10143-008-0168-y

21. Kim CH, Chung CK, Jahng TA, Park SB, Sohn S, Lee S (2015) Segmental kyphosis after cervical interbody fusion with standalone polyetheretherketone (PEEK) cages: a comparative study on 2 different PEEK cages. J Spinal Disord Tech 28:E17-E24. https:// doi.org/10.1097/bsd.0000000000000137

22. Kim SC, Kang SW, Kim SH, Cho KH, Kim SH (2009) Clinical and radiological outcomes of anterior cervical interbody fusion using hydroxyapatite spacer. Journal of Korean Neurosurgical Society 46: 300-304. https://doi.org/10.3340/jkns.2009.46.4.300

23. Kim SJ, Kim SD (2014) Anterior cervical discectomy and fusion using a double cylindrical cage versus an anterior cervical plating system with iliac crest autografts for the treatment of cervical degenerative disc disease. Journal of Korean Neurosurgical Society 55:12-17. https://doi.org/10.3340/jkns.2014.55.1.12

24. Klingler J-H, Sircar R, Kogias E, Scholz C, Volz F, Scheiwe C, Hubbe U (2014) PEEK cages versus PMMA spacers in anterior cervical discectomy: comparison of fusion, subsidence, sagittal alignment, and clinical outcome with a minimum 1-year followup. Sci World J 2014:11. https://doi.org/10.1155/2014/398396

25. Lee YS, Kim YB, Park SW (2014) Risk factors for postoperative subsidence of single-level anterior cervical discectomy and fusion: the significance of the preoperative cervical alignment. Spine 39: 1280-1287. https://doi.org/10.1097/brs.0000000000000400

26. Lin Q, Zhou X, Wang X, Cao P, Tsai N, Yuan W (2012) A comparison of anterior cervical discectomy and corpectomy in patients with multilevel cervical spondylotic myelopathy. European spine journal : official publication of the European Spine Society, the European Spinal Deformity Society, and the European Section of the Cervical Spine Research Society 21:474-481. https://doi.org/ 10.1007/s00586-011-1961-9

27. Mao N, Wu J, Zhang Y, Gu X, Wu Y, Lu C, Ding M, Lv R, Li M, Shi Z (2015) A comparison of anterior cervical corpectomy and fusion combined with artificial disc replacement and cage fusion in patients with multilevel cervical spondylotic myelopathy. Spine 40:1277-1283. https://doi.org/10.1097/brs.0000000000000957

28. Mastronardi L, Ducati A, Ferrante L (2006) Anterior cervical fusion with polyetheretherketone (PEEK) cages in the treatment of degenerative disc disease. Preliminary observations in 36 consecutive cases with a minimum 12-month follow-up. Acta Neurochir 148: 307-312; discussion 312. https://doi.org/10.1007/s00701-0050657-5

29. Mummaneni PV, Burkus JK, Haid RW, Traynelis VC, Zdeblick TA (2007) Clinical and radiographic analysis of cervical disc arthroplasty compared with allograft fusion: a randomized controlled clinical trial. Journal of neurosurgery Spine 6:198-209. https://doi.org/10.3171/spi.2007.6.3.198

30. Nandoe Tewarie RD, Bartels RH, Peul WC (2007) Long-term outcome after anterior cervical discectomy without fusion. European spine journal : official publication of the European Spine Society, the European Spinal Deformity Society, and the European Section of the Cervical Spine Research Society 16:1411-1416. https://doi.org/10.1007/s00586-007-0309-y

31. Niu CC, Liao JC, Chen WJ, Chen LH (2010) Outcomes of interbody fusion cages used in 1 and 2-levels anterior cervical discectomy and fusion: titanium cages versus polyetheretherketone (PEEK) cages. J Spinal Disord Tech 23:310-316. https://doi.org/ 10.1097/BSD.0b013e3181af3a84

32. Njoku I Jr, Alimi M, Leng LZ, Shin BJ, James AR, Bhangoo S, Tsiouris AJ, Hartl R (2014) Anterior cervical discectomy and fusion with a zero-profile integrated plate and spacer device: a clinical and radiological study: clinical article. Journal of neurosurgery Spine 21:529-537. https://doi.org/10.3171/2014.6.spine12951 
33. Orief T, Ramadan I, Seddik Z, Kamal M, Rahmany M, Takayasu M (2010) Comparative evaluation of bone-filled polymethylmethacrylate implant, autograft fusion, and polyetheretherketone cervical cage fusion for the treatment of single-level cervical disc disease. Asian Journal of Neurosurgery 5:46-56

34. Park HW, Lee JK, Moon SJ, Seo SK, Lee JH, Kim SH (2009) The efficacy of the synthetic interbody cage and Grafton for anterior cervical fusion. Spine 34:E591-E595. https://doi.org/10.1097/ BRS.0b013e3181ab8b9a

35. Park J-I, Cho D-C, Kim K-T, Sung J-K (2013) Anterior cervical discectomy and fusion using a stand-alone polyetheretherketone cage packed with local autobone : assessment of bone fusion and subsidence. Journal of Korean Neurosurgical Society 54:189-193. https://doi.org/10.3340/jkns.2013.54.3.189

36. Pereira EA, Chari A, Hempenstall J, Leach JC, Chandran H, Cadoux-Hudson TA (2013) Anterior cervical discectomy plus intervertebral polyetheretherketone cage fusion over three and four levels without plating is safe and effective long-term. Journal of clinical neuroscience : official journal of the Neurosurgical Society of Australasia 20:1250-1255. https://doi.org/10.1016/j. jocn.2012.10.028

37. Salame K, Ouaknine GE, Razon N, Rochkind S (2002) The use of carbon fiber cages in anterior cervical interbody fusion: report of 100 cases. Neurosurg Focus 12:E1. https://doi.org/10.3171/foc. 2002.12.1.2

38. Schmieder K, Wolzik-Grossmann M, Pechlivanis I, Engelhardt M, Scholz M, Harders A (2006) Subsidence of the wing titanium cage after anterior cervical interbody fusion: 2-year follow-up study. Journal of neurosurgery Spine 4:447-453. https://doi.org/10.3171/ spi.2006.4.6.447

39. Scholz M, Schnake KJ, Pingel A, Hoffmann R, Kandziora F (2011) A new zero-profile implant for stand-alone anterior cervical interbody fusion. Clin Orthop Relat Res 469:666-673. https://doi. org/10.1007/s11999-010-1597-9

40. Silber JS, Anderson DG, Daffner SD, Brislin BT, Leland JM, Hilibrand AS, Vaccaro AR, Albert TJ (2003) Donor site morbidity after anterior iliac crest bone harvest for single-level anterior cervical discectomy and fusion. Spine 28:134-139. https://doi.org/10. 1097/01.brs.0000041587.55176.67

41. Smith GW, Robinson RA (1958) The treatment of certain cervicalspine disorders by anterior removal of the intervertebral disc and interbody fusion. J Bone Joint Surg Am 40-A:607-624
42. Tani S, Nagashima H, Isoshima A, Akiyama M, Ohashi H, Tochigi S, Abe T (2010) A unique device, the disc space-fitted distraction device, for anterior cervical discectomy and fusion: early clinical and radiological evaluation. Journal of neurosurgery Spine 12:342346. https://doi.org/10.3171/2009.10.spine09283

43. Thome C, Leheta O, Krauss JK, Zevgaridis D (2006) A prospective randomized comparison of rectangular titanium cage fusion and iliac crest autograft fusion in patients undergoing anterior cervical discectomy. Journal of neurosurgery Spine 4:1-9. https://doi.org/ 10.3171/spi.2006.4.1.1

44. van Jonbergen HP, Spruit M, Anderson PG, Pavlov PW (2005) Anterior cervical interbody fusion with a titanium box cage: early radiological assessment of fusion and subsidence. The spine journal : official journal of the North American Spine Society 5:645-649; discussion 649. https://doi.org/10.1016/j.spinee.2005.07.007

45. Wu WJ, Jiang LS, Liang Y, Dai LY (2012) Cage subsidence does not, but cervical lordosis improvement does affect the long-term results of anterior cervical fusion with stand-alone cage for degenerative cervical disc disease: a retrospective study. European spine journal : official publication of the European Spine Society, the European Spinal Deformity Society, and the European Section of the Cervical Spine Research Society 21:1374-1382. https://doi.org/ 10.1007/s00586-011-2131-9

46. Yamagata T, Takami T, Uda T, Ikeda H, Nagata T, Sakamoto S, Tsuyuguchi N, Ohata K (2012) Outcomes of contemporary use of rectangular titanium stand-alone cages in anterior cervical discectomy and fusion: cage subsidence and cervical alignment. Journal of clinical neuroscience : official journal of the Neurosurgical Society of Australasia 19:1673-1678. https://doi. org/10.1016/j.jocn.2011.11.043

47. Yang JJ, Yu CH, Chang B-S, Yeom JS, Lee JH, Lee C-K (2011) Subsidence and nonunion after anterior cervical interbody fusion using a stand-alone polyetheretherketone (PEEK) cage. Clinics in Orthopedic Surgery 3:16-23. https://doi.org/10.4055/cios.2011.3.1.16

48. Yoo M, Kim WH, Hyun SJ, Kim KJ, Jahng TA, Kim HJ (2014) Comparison between two different cervical interbody fusion cages in one level stand-alone ACDF: carbon fiber composite frame cage versus polyetheretherketone cage. Korean Journal of Spine 11:127135. https://doi.org/10.14245/kjs.2014.11.3.127 